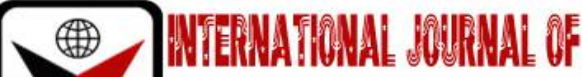 \\ בmas
}

ISSN 2278 - 0211 (Online)

\section{Oral Hygiene Practices among Adults in Obio/Akpor Local Government Area of Rivers State, Nigeria}

Etor, Nwakaji Emmanuel
Post Graduate Students, Department of Preventive and Social Medicine,
University of Port Harcourt, Nigeria
Isreal Queensley Oluomachukwu
Post Graduate Students, Department of Preventive and Social Medicine,
University of Port Harcourt, Nigeria
Onwukeme, Ijeoma Eucharia
Post Graduate Students, Department of Preventive and Social Medicine,
University of Port Harcourt, Nigeria
Obi, Ada Ruth
Post Graduate Students, Department of Preventive and Social Medicine,
University of Port Harcourt, Nigeria
Baridedum Uedeme Augustus
Post Graduate Students, Department of Preventive and Social Medicine,
University of Port Harcourt, Nigeria

\section{Abstract:}

This study focused on oral hygiene practices among adults in Obio/Akpor Local Government Area of Rivers State, Nigeria. The descriptive cross-sectional survey design was adopted for the study. The sample size for this study was four hundred. Data was collected using a semi-structured questionnaire and analyzed using descriptive statistics such as frequencies, percentages, and chi-square test was used for testing the hypotheses at 0.05 level of significance. The findings of the study revealed that majority (93.1\%) of the respondents practiced oral hygiene. The tested hypotheses showed that there was a significant association between age $\left(X^{2}=38.068, p<0.05\right)$, gender $\left(X^{2}=5.889, p<0.05\right)$ and educational level $\left(X^{2}=18.587, p<0.05\right)$ on practice of oral hygiene. It was concluded that socio-demographic characteristics such as age, gender, and education influences practices of oral hygiene. The study recommended amongst others that Government, ministries of health and non-governmental organizations at all level should mount more intensive enlightenment campaigns through public talk, seminars, conferences and workshop to create more awareness on the need for continues practice of oral hygiene to prevent diseases associated with them.

Keywords: Oral hygiene, practice, adults

\section{Introduction}

Oral hygiene is the science and practice of the recognition, treatment, and prevention of oral diseases (Darby \& Walsh, 2010). Good oral hygiene is the foundation for a healthy mouth and prevents $80 \%$ of all dental problems (Petersen, Bourgeois, Ogawa, Estupinan-Day \& Ndiaye, 2005). It is important that oral hygiene be carried out on a regular basis to enable prevention of dental diseases. Darby and Walsh (2010) asserted that the most common types of dental diseases are tooth decay (cavities, dental caries) and gum diseases, including gingivitis, and periodontitis. Regular brushing consists of brushing twice a day: after breakfast and before going to bed. Generally, American Dental Hygienists' Association (2013) recommend that teeth be cleaned professionally at least twice per year and included that professional cleaning includes tooth scaling, tooth polishing, and, if tartar has accumulated, debridement; this is usually followed by a fluoride treatment. In Nigeria, the awareness about dental disease and their impact on general health and the need to safeguard oral health and hygiene should be given utmost importance because of the increased use of tobacco, improper eating habits and inefficient maintenance of oral hygiene. It has been consistently reported that over $70 \%$ of adult Nigerians have periodontal disease (Petersen, 2004) a condition strongly associated with oral hygiene status. Although the prevalence of dental caries is low in Nigeria, between $10 \%$ and 20\%; it remains a disease of public health interest because most carious lesions remain untreated (Umanah \& Braimoh, 2017). It is important to review the practices of the oral health of adults, even though they are educated, with the objectives of inculcating healthy lifestyles practices to last for a lifetime. However, in rural areas, little is known about their oral health practices despite all research work that have been written. Hence, this study tends to investigate oral hygiene practices among adults in Obio/Akpor Local Government Area of Rivers State. 


\subsection{Purpose of the Study}

The purpose of this study is to investigate oral hygiene practices and factors influencing the choice of oral hygiene materials among adults in Obio/Akpor Local Government Area of Rivers State. Specifically, the objectives of this study are to:

- Investigate the level of oral hygiene practices among adults of Obio/Akpor Local Government Area of Rivers State

- $\quad$ examine the relationship between age and practice of oral hygiene among adults of Obio/Akpor Local Government Area of Rivers State

- $\quad$ examine the relationship between gender and practice of oral hygiene among adults of Obio/Akpor Local Government Area of Rivers State

- $\quad$ examine the relationship between education and practice of oral hygiene among adults of Obio/Akpor Local Government Area of Rivers State

\subsection{Research Questions}

The study seeks to provide answers to the following questions:

- What is the level of oral hygiene practices among adults of Obio/Akpor Local Government Area of Rivers State?

- What is the relationship between age and practice of oral hygiene among adults of Obio/Akpor Local Government Area of Rivers State?

- What is the relationship between gender and practice of oral hygiene among adults of Obio/Akpor Local Government Area of Rivers State?

- What is the relationship between educational level and practice of oral hygiene among adults of Obio/Akpor Local Government Area of Rivers State?

\subsection{Research Hypotheses}

The following null hypotheses were formulated to guide the study and shall be tested at 0.05 alpha levels.

- $\mathrm{Ho}_{1}$ : There is no significant relationship between age and practice of oral hygiene among adults of Obio/Akpor Local Government Area of Rivers State

- $\mathrm{H}_{02}$ : There is no significant relationship between gender and practice of oral hygiene among adults of Obio/Akpor Local Government Area of Rivers State

- $\mathrm{H}_{03}$. There is no significant relationship between educational level and practice of oral hygiene among adults of Obio/Akpor Local Government Area of Rivers State

\subsection{Research Methods}

'The study adopted a descriptive survey research design. The population of the study consisted of all adults in Obio/Akpor Local Government Area of Rivers State.A sample size of four hundred was determined using the Yaro Yammane formula for a finite population. A self-developed and structured questionnaire was composed to extract information on the variables of the study. The researcher personally administered the questionnaire to respondents. The questionnaire was designed to obtain responses using alternative responses pattern.Data collected were entered into the computer using Statistical Package for Social Science (SPSS 20.0) software for analysis and data were presented using frequency, percentages and chi-square.

\section{Results}

\begin{tabular}{|c|c|c|}
\hline Socio-Demographic Characteristics* & Frequency (F) & Percentage (\%) \\
\hline Gender & & \\
Male & 199 & 55.3 \\
Female & 161 & 44.7 \\
Total & $\mathbf{3 6 0}$ & $\mathbf{1 0 0 . 0}$ \\
Age & & 18.1 \\
\hline 15-20 years & 65 & 16.7 \\
\hline 21-25years & 60 & 23.9 \\
\hline 26-30years & 86 & 13.6 \\
\hline 31-35years & 49 & 27.8 \\
\hline 36 years and above & 100 & $\mathbf{1 0 0 . 0}$ \\
Total & $\mathbf{3 6 0}$ & 8.9 \\
\hline Educational level & & - \\
\hline Non formal & 32 & 36.9 \\
\hline Primary & - & 54.2 \\
\hline Secondary & 133 & 100.0 \\
\hline Tertiary & 195 & \\
\hline Total & 360 & \\
\hline Table & & \\
\hline Pacio-Demographic Chara & & \\
\hline
\end{tabular}

Table 1: Socio-Demographic Characteristics of Respondents 
Table 1 shows the socio-demographic characteristics of respondents. The table revealed that 55.3\% of the respondents were males while less than half $(44.7 \%)$ were females. It showed that $18.1 \%$ of the respondents were within the ages of $15-20$ years, $16.7 \%$ 21-25years, $23.9 \%$ 26-30 year, $13.6 \% 31-35$ years and $27.8 \% 36$ years and above. The table also revealed that $8.9 \%$ of the population had no formal education, $36.6 \%$ had secondary education while $54.2 \%$ had tertiary education.

\begin{tabular}{|c|c|c|}
\hline \multicolumn{2}{|c|}{$\begin{array}{c}\text { Practice of Oral Hygiene } \\
\text { Yes }\end{array}$} & Total \\
\hline $65(100)$ & $0(0.0)$ & $65(100)$ \\
\hline $60(100)$ & $0(0.0)$ & $60(100)$ \\
\hline $86(100)$ & $0(0.0)$ & $86(100)$ \\
\hline $41(83.7)$ & $8(16.3)$ & $49(100)$ \\
\hline $83(83.0)$ & $17(17.0)$ & $100(100)$ \\
\hline $335(93.1)$ & $25(6.9)$ & $360(100)$ \\
\hline
\end{tabular}

Table 2: Practice of Oral Health

The table showed that $93.1 \%$ of the total population had good oral hygiene practices.

\subsection{Test of Hypotheses}

- Hypothesis 1: There is no significant relationship between age and practice of oral hygiene among adults of Obio/Akpor Local Government Area of Rivers State

\begin{tabular}{|c|c|c|c|c|c|c|c|}
\hline Age & \multicolumn{2}{|c|}{$\begin{array}{c}\text { Practice of Oral Hygiene } \\
\text { Yes }\end{array}$} & Total & Df & X $^{2}$-value & p-value & Decision \\
\hline $15-20$ & $65(100)$ & $0(0.0)$ & $65(100)$ & 4 & 38.068 & .000 & $\mathrm{H}_{\mathrm{o}}$ Rejected \\
\hline $21-25$ & $60(100)$ & $0(0.0)$ & $60(100)$ & & & & \\
\hline $26-30$ & $86(100)$ & $0(0.0)$ & $86(100)$ & & & & \\
\hline $31-35$ & $41(83.7)$ & $8(16.3)$ & $49(100)$ & & & & \\
\hline$\geq 36$ & $83(83.0)$ & $17(17.0)$ & $100(100)$ & & & & \\
\hline Total & $335(93.1)$ & $25(6.9)$ & $360(100)$ & & & & \\
\hline
\end{tabular}

Table 3: Chi-Squared Test Showing Relationship between Age and Practice of Oral Hygiene

The table shows the Chi-squared test of significant relationship between age and practice of oral hygiene among adults of Obio/Akpor Local Government Area. The finding of the study showed that age has a significant relationship with practice of oral hygiene $\left(X^{2}-\right.$ value $\left.=38.068, \mathrm{df}=4, \mathrm{p}<0.05\right)$. Therefore, the null hypothesis which states that there was no significant relationship between age and practice oral hygiene among adults of Obio/Akpor Local Government Area of Rivers State was rejected.

- Hypothesis 2: There is no significant relationship between gender and practice of oral hygiene among adults of Obio/Akpor Local Government Area of Rivers State.

\begin{tabular}{|c|c|c|c|c|c|c|c|}
\hline Gender & \multicolumn{2}{|c|}{$\begin{array}{c}\text { Practice of Oral Hygiene } \\
\text { Yes }\end{array}$} & Total & df & $\mathbf{X}^{2}$-value & p-value & Decision \\
\hline Male & $191(96.0)$ & $8(4.0)$ & $199(0.0)$ & 1 & 5.889 & .015 & $\mathrm{H}_{\mathrm{o}}$ Rejected \\
\hline Female & $144(89.4)$ & $17(10.6)$ & $161(100)$ & & & & \\
\hline Total & $335(93.1)$ & $25(6.9)$ & $360(100)$ & & & & \\
\hline
\end{tabular}

Table 4: Chi-Squared Test Showing Relationship between Gender and Practice of Oral Hygiene

The table shows the Chi-squared test of significant relationship between gender and practice oral hygiene among adults of Obio/Akpor Local Government Area. The finding of the study showed that there was a significant relationship between gender and practice oral hygiene $\left(X^{2}-\right.$ value $\left.=5.889, \mathrm{df}=1, \mathrm{p}<0.05\right)$. Therefore, the null hypothesis which states that there was no significant relationship between gender and practice oral hygiene among adults of Obio/Akpor Local Government Area of Rivers State was rejected.

- Hypothesis 3: There is no significant relationship between educational level and practice of oral hygiene among adults of Obio/Akpor Local Government Area of Rivers State

\begin{tabular}{|c|c|c|c|c|c|c|c|}
\hline Education & \multicolumn{2}{|c|}{$\begin{array}{c}\text { Practice of Oral Hygiene } \\
\text { Yes }\end{array}$} & Total & df & $\mathbf{X}^{2}$-value & p-value & Decision \\
\hline None & $24(75.0)$ & $25(25.0)$ & $32(100)$ & 2 & 18.587 & .000 & $\mathrm{H}_{\mathrm{o}}$ Rejected \\
\hline Secondary & $124(93.2)$ & $9(6.8)$ & $133(100)$ & & & & \\
\hline Tertiary & $187(95.9)$ & $8(4.1)$ & $195(100)$ & & & & \\
\hline Total & $335(93.1)$ & $25(6.9)$ & $360(100)$ & & & & \\
\hline
\end{tabular}

Table 5: Chi-Squared Test Showing Relationship between Educational Level and Practice of Oral Hygiene 
The table shows the Chi-squared test of significant relationship between educational level and practice oral hygiene among adults of Obio/Akpor Local Government Area. The finding of the study showed that educational level has a significant relationship with practice of oral hygiene $\left(X^{2}\right.$-value $\left.=18.587, \mathrm{df}=2, \mathrm{p}<0.05\right)$. Therefore, the null hypothesis which states that there was no significant relationship between educational level and practice of oral hygiene among adults of Obio/Akpor Local Government Area of Rivers State was rejected.

\section{Discussion}

The finding of the study showed that majority (93.1\%) of the respondents practiced oral hygiene. The finding of the study corroborates that of Christensen et al (2011) who discovered in their study that participants had good practice of oral hygiene. The finding is also in keeping with of Eman et al (2019) where good practice of oral hygiene was noticed. The good practice of oral hygiene reported in both studies is mainly due to the educational attainment of study participants as education contributes to effective personal hygiene. However, the present study differs from that of Tubaishat et al (2005), Aliyu et al (2017) and Adeyemi et al (2014) who reported low practice of oral hygiene among their study participants. The low practice of oral hygiene might be attributed to the fact that both studies were carried out in different geographical location. Education and culture may also play a vital role in their differences as individuals may likely practice the method of oral cleaning prevalent in their societies.

The finding of the study showed that age has a significant relationship with practice of oral hygiene. The finding corroborates that of Eman et al (2019) who discovered that age significantly influences practice of oral hygiene. The finding is also in keeping with that of Umanah and Bramoh (2017), Tatiana et al (2011) who also discovered that there is a significant relationship between age and oral hygiene practice. The similarities in these studies might be due to the fact that as age increases, there is the tendency that some persons will become hygiene conscious especially as they begin to socialize. However, the study differs from that of Aliyu et al (2017) and that of Anitha et al (2015) who both reported that age has nothing to do with oral hygiene practices. This may be attributed to the fact that the culture of the people sometimes is more adhered to especially in the rural settings where cultural practices influences human behavior.

The finding of the study showed that gender has a significant relationship with practice of oral hygiene. The finding is in keeping with the study of Tatiana et al (2011) and Azodo and Unamatokpa (2012) who both reported in their studies that gender is significantly associated with oral hygiene. They also reported that females tend to practice more oral hygiene than men. This may be attributed to the fact that females are usually hygiene conscious hence; they will like to choose oral hygiene materials that will effectively suit them and may them more comfortable compared to the most of the men who don't really care. However, the findingof Aliyu et al (2017) is quite different from the present study as it relates that culture and the media including cost and availability of oral hygiene materials play in important role in the choices and practices of oral hygiene materials. Hence, individuals are sometimes restricted to what they have and can afford. However, geographical location and education also plays important roles.

The finding of the study showed that educational level has a significant relationship with oral hygiene. The finding is in keeping with that of Christensen et al (2011) and Adeyemi et al (2014) who found a significant association between education and practice of oral hygiene. The finding is also similar to that of Eman et al (2019) who reported that there is a significant relationship between education and practice of oral hygiene material. This might be attributed to the fact the more educated a person is, the more knowledge and awareness he or she gets to adequately practice hygiene that will be of benefit to his/her health compared to those who are not educated. However, the study of Tubaishat (2005) and Aliyu et al (2017) seems to be different from that of the present study. This might be due to the fact that education does not really count when it comes to practice of oral hygiene especially when an individual has developed negative health behavior towards hygiene practices.

\section{Conclusion}

Based on the findings of the study, it was concluded that students had good practice of oral hygiene and that sociodemographic characteristics such as age, gender, and education influences the practice of oral hygiene.

\section{Recommendation}

In view of the findings of this study, the following recommendations were made:

- Government, ministries of health and non-governmental organizations at all level should mount more intensive enlightenment campaigns through public talk, seminars, conferences and workshop to create more awareness on the need for nutritional education and practice of oral hygiene to prevent diseases associated with poor oral hygiene.

- The government, ministries of health and other relevant health agencies should embark on health education and awareness campaign on the dangers and prevention of tooth decay.

- The government, school authorities and stakeholders should put in place special programs targeting young women and men including children on how to prevent behaviors that put them at risk of poor knowledge, attitude and practice of oral hygiene. 


\section{References}

i. Adeyemi, O. O., Abiola, A. A \& Olufemi, O. (2014). Self-rated oral health status, oral health service utilization, and oral hygiene practices among adult Nigerians,BMC Oral Health, 2014; 14:140, doi.org/10.1186/1472-6831$14-140$

ii. Aliyu, I., Michael, G. C., Teslim, L. O. \& Ibrahim, Z. F. (2017). Oral hygiene practices among patients seen in the general outpatient clinic of a tertiary health center. SRM J Res Dent Sci, 2017;8:152-6

iii. Anitha, L.Jaideep, M.,Rajapriya, P. (2015). Influence of Media in the Choice of Oral HygieneProductsUsed Among the Population of Maduravoyal, Chennai, India, J Clin Diagn Res, 9 (10), ZC06-ZC08.

iv. American Dental Hygienist Association (2013). Position paper on oral prophilaxis. 29 april 1998.Retrieved 2012

v. American Dental Association brochure (2008). "Oral Longevity," page 2Archived 2010-11-19 at the Wayback Machine Retrieved June 12, 2008.

vi. Azodo, C. C. \& Unamatokpa, B (2012). Gender difference in oral health perception and practices among Medical House Officers, Russian Open Medical Journal, 1 (2), 4-7

vii. Christensen, L. B., Petersen, P. E., Krustrup, U\&Kjøller, M. (2011). Self-reported oral hygienepractices among adults in Denmark, Community Dent Health,20 (4), 229-35.

viii. Darby, M. L., \& Walsh, M. (2009). Dental Hygiene-E-Book: Theory and Practice. Elsevier health sciences.

ix. Eman, A., Basema, S., Mohammed, E., Samer, H. \& Mohammed, B (2019). Oral Health Knowledge and Behavior among Adults in the United Arab Emirates, BioMed Research International, 2019;1-7. doi.org/10.1155/2019/7568679

x. Petersen, P. E., Bourgeois, D., Ogawa, H., Estupinan-Day, S. Ndiaye, C. (2005). The global burden of oral diseases and risks to oral health. Bull World Health Organ 2005; 83:661- 9.

xi. Tubaishat, R. S., Darby, M. B., Bauman, D. B. \& Box, C. E. (2005). Use of miswak versus toothbrushes: oral health beliefs and behaviours among a sample of Jordanian adults, International Journal of Dental Hygiene, doi.org/10.1111/j.1601-5037.2005.00136.x

xii. Umanah, A. U \& Braimoh, O. B (2017). Oral hygiene practices and factors influencing the choice of oral hygiene materials among undergraduate students at the University of Port Harcourt, Rivers State, Nigeria. J Dent Allied Sci2017; 6:3-7 